Relations industrielles

Industrial Relations

\title{
Government reviews
}

\section{Gaston Cholette}

Volume 5, numéro 2, novembre 1949

URI : https://id.erudit.org/iderudit/1023289ar

DOI : https://doi.org/10.7202/1023289ar

Aller au sommaire du numéro

Éditeur(s)

Département des relations industrielles de l’Université Laval

ISSN

0034-379X (imprimé)

1703-8138 (numérique)

Découvrir la revue

Citer cet article

Cholette, G. (1949). Government reviews. Relations industrielles / Industrial Relations, 5(2), 19-19. https://doi.org/10.7202/1023289ar

Tous droits réservés @ C Département des relations industrielles de l’Université Laval, 1949
Ce document est protégé par la loi sur le droit d'auteur. L’utilisation des services d'Érudit (y compris la reproduction) est assujettie à sa politique d'utilisation que vous pouvez consulter en ligne.

https://apropos.erudit.org/fr/usagers/politique-dutilisation/ 
REVIEWS ON INDUSTRIAL RELATIONS

\section{GOVERNMENT REVIEWS}

Governmental Journals on Labour Relations occupy a choice position. The unpublished information and statistics of a national and official character which only the publications of this kind are able to furnish are of primary importance. The Industrial Relations Bulletin hastens then to present its readers with the principal reviews which fall under this category.

Aware that they have many characteristics in common we have thought it timely to group here thase of the following countries: Canada, United States, France and Belgium with the addition of the International Labour Review published by the International Labour Office. Here are the titles of the reviews of these contries in the same order as in the preceeding sentence: The Labour Gazette, Monthly Labour Review, Revue française du travail, Revue du travail and the International Labour Review.

¿THE LABOUR GAZETTE 》 is a monthly periodical of a hundred to a hundred and fifty pages published by the Federal Ministry of Labour. It has been in existence for fifty years. Here is a list of its headings: «The Working Month in Review 》, \& Notes on Questions of the Day », \& The International Labour Organization 》, \&Industrial Relations and Conciliation \, Collective Agreements and Wage Scales >, Fair Wages in Government Enterprises », \& Labour Legislation », « Unemployment Insurance », «The Current Situation of Employment », « Cost of Living Prices », « Strikes and Lock-outs », < Labour Statistics $\gg$. It might be pointed out here that the statistics furnished in this publication are extremely exact and up-to-date since the Federal Bureau of Statistics is one of the best organized institutions of its kind in the world. Subscription price: \$1.00. Write: Ministry of Labour, Ottawa.

<MONTHLY LABOR REVIEW * is a periodical of a hundred to a hundred and fifty pages published by the Bureau of Labor Statistics, United States Department of Labor. It contains regularly three or four special articles, reports on a dozen different subjects under the headings of « Summaries of Studies and Reports», technical notes bearing usually on statistical problems and finally a section entitled \& Departments $>$ in which we find regularly five items on the following matters: The working month in review, Judicial Decisions of Interest to Workers, Report of recent labor events, publications on Labor Relations, Labor Statistics. Subscription price: \$5.75. Write: Superintendent of Documents, U.S. Government Printing Office, Washington 25, D.C.

\& LA REVUE FRANÇAISE DU TRAVAIL, is a monthly publication of about 150 pages, issued by the Ministry of Labour and Social Security in France. It usually contains two or three important articles and the following items: « Social Action in France », \& Social Action in Foreign Countries >, « Statistics >. Subscription price: 1650 francs. Write: Presses universitaires de France, 108, Boulevard Saint-Germain, Paris VIe.
CLA REVUE DE TRAVAIL > a monthly publication of about 200 pages, is the mouth-piece of the Ministry of Labour and State Insurance of Belgium. Here is the list of its principal items: Labour Conditions 》, - Employment and Unemployment >, \& Social Security \$, - Social Action 》, e International Social Action 》, e Report on Parliamentary Work $\gg$, Cfficial Acts and Documents $\gg$, - Jurisprudence \$, Economic and Demographic Statistics \, Bibliography \. Subscription price: 450 francs. Write: 2, rue Lambermont, Bruxelles.

CTHE INTERNATIONAL LABOUR REVIEW , monthly periodical of 100 to 150 pages, is the organ of the International Labour Office. It contains leading articles, written by the services of the Office or by its outside collaborators, which treat of the evolution of social policy in different countries and on the international level. It also contains documentary reports grouped under the heading \&eports and Inquiries $>$; analyses of official reports of general interest and results of the researches undertaken by the I.L.O. There are statistics on the costof-living, unemployment, employment, wages and working hours which the Office is the only one to publish under a form as complete and systematic and finally a bibliography of an international character. Subscription price: $\$ 5.00$. Write to: International Labour Office, Genève, Suisse.

G. C.

\section{PERSONNEL JOURNAL}

c Personnel Journal s claims to be in chronological order the first of the reviews devoted to problems of personnel and industrial relations. It dates from 1922.

It is a monthly publication of about forty pages containing, usually, five or six articles, a couple of short editorials, a section reserved for the letters of readers and news of books and reviews, etc.

It is got out at Swarthmore, Pennsylvania, under the direction of Edward N. Hay. The greater number of contributors are men who have important positions in large enterprises. Many articles, on the other hand, are written by university professors. So it has the advantage of presenting studies which art the fruit of practical experience and of scientific research.

c Personnel Journal s furnishes above all articles which set forth facts, which present experiences. One does not often find in it works of philosopical thought on the enterprise and labour relations.

Most of the articles published in it deal with administration of personnel, in particular with job evaluation. A very well done study on this subject appeared in the April 1949 number under the title of $\&$ Management Positions Can be Evaluated Successfully >. A really remarkable experience, accomplished by a large establishment during a period of three years, is recounted here. The aim was to fix, as scientifically as possible, the salary scale of its senior employees by taking into account the extent of knowledge, the need for decision and responsibility deo manded in the execution of each task.

One subscribes to this review at a price of six dollars a year by addressing Personnel Journal s. Swarthmore, Pa., U.S.A.
G.C. 